\title{
5th EuroNOTES/IFCARS/ISCAS Workshop on NOTES: An Interdisciplinary Challenge
}

Chair: Hubertus Feussner, MD (D) 